INFO ARTIKEL

Riwayat Artikel:

Diterima : 05 Juni 2018

Disetujui : 12 Agustus 2018

\title{
PENDIDIKAN
}

\section{PERAN SISWA PADA PROGRAM ADIWIYATA DALAM MENGURANGI PEMANASAN GLOBAL DI SMA NEGERI 4 KABUPATEN LAHAT}

\section{Ipo Astria ${ }^{1}$, Mega Kusuma Putri}

\author{
${ }^{1}$ SMPT Pesantren Al-Quds, ${ }^{2}$ Pendidikan Geografi Universitas PGRI Palembang \\ $(\bowtie)^{2}$ puteri.mega@ rocketmail.com
}

\begin{abstract}
ABSTRAK
Masalah dalam penelitian ini yaitu bagaimanakah peran siswa pada program adiwiyata dalam mengurangi pemanasan global di SMAN 4 Lahat. Tujuan dari penelitian ini yaitu untuk mengetahui peran siswa pada Program Adiwiyata dalam mengurangi pemanasan global di SMAN 4 Lahat. Metode penelitian yang digunakan adalah metode survei dan pendekatan yang digunakan yaitu pendekatan kualitatif. Siswa yang ingin di wawancara yaitu kelas XII, karena kelas XII sudah lebih memahami akan kegiatan-kegiatan yang berhubungan dengan Program Adiwiyata. Teknik pengumpulan data menggunakan observasi, wawancara dan dokumentasi. Teknik pengambilan data menggunakan wawancara dan teknik analisis data menggunakan reduksi data. Hasil penelitian menunjukkan bahwa peran siswa di SMA Negeri 4 Lahat tersebut cukup baik, hal itu terlihat dari seluruh siswa di Sekolah tersebut ikut berpartisipasi dalam kegiatan kebersihan yang dilakukan setiap hari yaitu pagi hari.
\end{abstract}

Kata kunci: Kerusakan Lingkungan, Industri Batu Bata, Sumber Belajar

\section{PENDAHULUAN}

Adiwiyata mempunyai pengertian atau makna sebagai tempat yang baik dan ideal di mana dapat diperoleh segala ilmu pengetahuan dan berbagai norma serta etika yang dapat menjadi dasar manusia menuju terciptanya kesejahteraan hidup kita dan menuju kepada cita-cita pembangunan berkelanjutan (Kerjasama Kementrian Lingkungan Hidup dengan Kementrian Pendidikan dan Kebudayaan, 2012:3).

Pemanasan global atau global warming adalah kenaikan suhu bumi atau meningkatnya temperatur suhu rata-rata atmosfer, laut, dan daratan bumi. Penyebab dari peningkatan yang cukup drastis ini adalah pembakaran bahan bakar fosil. (Hadi Alikodra dan Syaukani, 2008:21). Pemanasan global di sekolah di sebabkan oleh beberapa faktor yaitu, (1) Polusi udara yang di sebabkan oleh kendaraan pribadi; (2) Penggunaan Energi listrik yang berlebihan; (3) Sampah-sampah yang sulit di uraikan. Upaya yang dapat dilakukan untuk mengurangi pemanasan global di sekolah, yaitu menghemat penggunaan listrik yang dapat mengurangi hawa panas. Berjalan kaki ke sekolah jika jarak tempuh dari rumah dan sekolah relatif dekat dan menggunakakn angkutan umum jika jarak tempuh dari rumah ke sekolah relatif jauh.

Seiring berjalannya waktu, pemerintah dan masyarakat mulai sadar akan bahaya kerusakan lingkungan. Pemerintah mulai mengadakan berbagai program yang bertujuan untuk menciptakan lingkungan yang bersih dan sehat, diantaranya melalui program pendidikan lingkungan hidup. Pendidikan lingkungan hidup yang diterapkan di sekolah merupakan kurikulum 
baru yang lebih menekankan pada pengetahuan, tindakan serta kesadaran masyarakat mengenai pembangunan berkelanjutan.

Salah satu program pendidikan lingkungan di sekolah adalah program adiwiyata, yaitu penghargaan yang di berikan kepada sekolah yang berwawasan lingkungan yang dapat mengolah sampah dan mencegah efek pemanasan global dengan cara reduce, reuse, dan recycle. Tujuan dari program Adiwiyata adalah untuk mewujudkan warga sekolah yang bertanggung jawab dalam upaya perlindungan dan pengelolaan lingkungan hidup dan penerapan perilaku manusia terhadap alam untuk melindungi dan melestarikan keberadaan alam agar tetap terjadi keberlanjutan kehidupan (Panduan Adiwiyata Sekolah Peduli dan Berbudaya Lingkungan, 2011:3).

Keuntungan program adiwiyata bagi sekolah adalah: (1) Meningkatkan efesiensi penggunaan dana BOS; (2) Menciptakan kebersamaan warga sekolah dan kondisi belajar mengajar yang lebih nyaman dan kondusif; (3) Meningkatkan upaya perlindungan dan pengelolaan lingkungan hidup melalui kegiatan pengendalian pencemaran; (4) Pengendalian kerusakan dan pelestarian fungsi lingkungan di sekolah. Berdasarkan uraian diatas, bahwa peran siswa yang dimaksud yaitu kesadaran siswa dalam menjaga lingkungan hidup di sekolah.

Tindakan yang lebih baik dalam menciptakan suasana lingkungan sekolah yang hijau guna mengurangi pemanasan global yaitu dengan membuat taman sekolah, berarti memperbanyak jumlah pohon-pohon atau tanaman-tanaman yang ada di sekolah. Tanaman tersebut berfungsi menyerap karbon dioksida dan menghasilkan oksigen, dengan adanya taman sekolah tentu lingkungannya menjadi indah dan sejuk.

Hal ini berarti siswa berperan menjaga lingkungan sekitar sekolah, seperti menjaga tanaman yang ada di taman sekolah dan sekitarnya, ikut serta dalam kegiatan kebersihan kelas dan halaman sekolah setiap pagi. Selain itu siswa dapat mengelola sampah juga meningkatkan kualitas layanan makanan sehat di sekolah. Kondisi seperti itu diharapkan dapat menciptakan kegiatan belajar mengajar di sekolah menjadi lebih menyenangkan.
Fokus dalam penelitian ini adalah Partisipasi siswa di SMA Negeri 4 Kabupaten Lahat terhadap peningkatan kualitas pelayanan makanan sehat dan pengembangan sistem pengelolaan sampah dalam upaya menjadikan sekolah yang ramah lingkungan dan mengurangi pemanasan global.

Agar penelitian lebih terarah, terfokus dan tidak menyimpang dari sasaran pokok penelitian, peneliti melakukan pembatasan masalah, yaitu:

1. Melihat pengelolaan lingkungan hidup di SMA Negri 4 Kabupaten Lahat dalam upaya peningkatan kualitas pelayanan makanan sehat dan pengembangan sistem pengelolaan sampah untuk menjadikan sekolah sehat dan dalam upaya mengurangi pemanasan global.

2. Subjek penelitian ini adalah siswa kelas XII SMA Negeri 4 Lahat.

Adapun yang menjadi tujuan penelitian ini adalah untuk melihat peran siswa pada program Adiwiyata dalam mengurangi pemanasan global di SMA Negeri 4 Lahat dan melihat apakah program tersebut berjalan dengan baik.

\section{METODOLOGI PENELITIAN}

Adapun metode yang digunakan dalam penelitian ini adalah metode survei. Penelitian survei merupakan penyelidikan dengan gerak ke arah luas dan merata (Mahmud, 2011:102). Penelitian ini digunakan untuk mengetahui peran siswa pada Program Adiwiyata terhadap pemanasan global.

Pendekatan dalam penelitian ini adalah pendekatan kualitatif. Pendekatan kualitatif adalah tampilan yang berupa kata-kata lisan atau tertulis yang dicermati oleh peneliti, dan benda-benda yang diamati sampai detailnya agar dapat ditangkap makna yang tersirat dalam dokumen atau bendanya (Arikunto, 2010:22).

Prosedur penelitian atau langkah penelitian dalam penelitian kualitatif baru diketahui dengan mantap dan jelas setelah penelitian selesai (Arikunto, 2010:28). Prosedur pengumpulan data primer dalam penelitian ini adalah dengan teknik observasi dan wawancara, sedangkan data sekunder memalui teknik dokumentasi. 
Tahap-tahap dalam penelitian ini yaitu yang pertama melakukan observasi ke sekolah terlebih dahulu mengenai waktu penelitian dan melihat keadaan lingkungan serta keikutsertaan siswa dalam rangka mengurangi pemanasan global pada program adiwiyata sekolah. Selanjutnya melakukan wawancara kepada siswa dan guru yang bersangkutan pada program adiwiyata di sekolah tersebut, sebelum wawancara kepada siswa peneliti terlebih dahulu menjelaskan mengenai program adiwiyata tersebut dan dokumentasi untuk melengkapi data-data dalam penelitian tersebut misalnya berupa foto-foto dan bukti-bukti penting dalam program adiwiyata (piala dan piagam). Selanjutnya data tersebut dapat digabungkan dengan hasil data observasi dan data wawancara yang relevan menjadi suatu data yang akurat.

Proses analisis data dalam penelitian ini menggunakan aktivitas analisis data sesuai dengan Miles dan Huberman, dalam (Sugiyono, 2009:247) yaitu:

1. Reduction (reduksi data) berarti merangkum data, memfokuskan pada hal-hal yang penting mencari tema polanya dan membuang hal-hal yang tidak penting dengan demikian data yang telah direduksi akan memberikan gambaran yang lebih jelas dan mempermudah peneliti untuk melakukan pengumpulan dan selanjutnya, dan mencari bila diperlukan. Dalam penelitian ini data yang direduksi adalah hasil dari pengumpulan data dari observasi dan wawancara.

2. Display (penyajian data) bisa dilakukan dalam bentuk uraian singkat, bagan, hubungan antara kategori sehingga mempermudah untuk memahami apa yang terjadi. Dalam penelitian ini data yang disajikan adalah hasil dari observasi dan wawancara.

3. Conclusion drawing (kesimpulan data) adalah penarikan kesimpulan dan verifikasi. Kesimpulan awal masih bersifat sementara tetapi apabila kesimpulan pada tahap awal, didukung oleh bukti-bukti yang valid dan konsisten saat peneliti kembali ke lapangan mengumpulkan data, maka kesimpulan yang dikemukakan merupakan kesimpulan yang kredibel.

Peneliti menarik kesimpulan dan melakukan verifikasi dengan mencari makna setiap gejala yang diperolehnya dari lapangan, mencatat keteraturan dan konfigurasi, alur kausalitas dari fenomena dan proposisi.

\section{HASIL DAN PEMBAHASAN}

\section{Kegiatan Kebersihan}

Setiap pagi hari siswa membersihkan kelas mereka masing-masing berdasarkan jadwal piket sesudah kegiatan imtaq. Selanjutnya siswa juga membersihkan lingkungan sekitar kelas seperti lapangan dan taman dibantu teman-teman sesama siswa lainnya walaupun mereka bukan mendapatkan jadwal piket pada hari tersebut tetapi siswa-siswa di SMA Negeri 4 Kabupaten lahat sudah memiliki kesadaran akan tanggung jawabnya dalam menjaga kebersihan lingkungan.

Siswa yang mendapatkan jadwal piket pada hari tersebut bertugas membersihkan ruang kelas dan koridor depan kelas juga sekitar kelas, sedangkan siswa yang tidak mendapat jadwal piket pada hari tersebut maka mereka saling bantu dan gotong-royong dalam membersihkan lapangan, taman dan lingkungan sekitar sekolah. Kegiatan tersebut rutin dilakukan setiap harinya.

Kegiatang kebersihan di SMA Negeri 4 Kabupaten Lahat dilakukan setiap hari sesudah kegiatan imtaq berlangsung, karena di sekolah tersebut tidak ada hari khusus untuk kegiatan kebersihan. Oleh karena itulah guru beserta siswa saling bantu-membantu dalam hal kegiatan kebersihan lingkungan sekolah. Siswa dengan diawasi oleh guru-guru yang bertugas aktif menjaga kebersihan kelas dan lingkungan sekolah dengan selalu rutin membagi-bagi tugas setiap hari dan dengan kesadaran masing-masing siswa.

Kegiatan siswa setiap pagi antara lain menyapu rumput serta lapangan yang banyak dijatuhi dedaunan, membuang sampah pada kotak sampah lalu dibuang ke bank sampah, menyapu dan mengepel ruang serta koridor kelas, menyiram tanaman dan lain sebagainya. Oleh sebab itulah lingkungan sekolah dan sekitar sekolah selalu terlihat bersih dan terasa sejuk.

Lingkungan SMA Negeri 4 Kabupaten Lahat yang selalu dijaga kebersihannya oleh warga sekolah menjadi terasa sejuk dan didukung dengan 
tanaman disekitar dan di lingkungan sekolah yang selalu dijaga oleh warga sekolah yaitu guru dan siswa, sehingga hal tersebut berpengaruh terhadap keadaan lingkungan yang menjadi sejuk dan mengurangi hawa panas akibat pemanasan global.

Selain itu juga di SMA Negeri 4 Kabupaten Lahat menyediakan asrama, dan asrama tersebut lebih mengutamakan siswa yang diluar kota, sisanya baru untuk kelas X lainnya. Adanya asrama tersebut cukup membantu mengurangi kendaraan bermotor bagi siswa yang dapat menyebabkan volusi udara dari asap motor tersebut dan berakibat pemanasan global.

Asrama dan gedung-gedung sekolah dikelilingi oleh taman dan pepohonan yang membuat suasana di sekolah menjadi sejuk dan asri. Hal itu tak lepas dari kerja sama guru dan siswa dalam menjaga lingkungan sekolah agar selalu sejuk. Kebersihan sekolah dan asrama di SMA Negeri 4 Kabupaten Lahat ini sudah diatur berdasarkan jadwal piket perkelas dan perkamar, sehingga kebersihan selalu terjaga.

Siswa yang tinggal di asrama sudah terlatih untuk bangun pagi dan menyelesaikan tugas-tugas kebersihan asrama dan lingkungan sekitarnya. Sama halnya dengan menjaga kebersihan lingkungan sekolah di SMA Negeri 4 Lahat, siswa yang bertugas menjaga kebersihan asrama juga dibuat berdasarkan jadwal piket perkamar masingmasing.

\section{Inventarisasi Alat Kebersihan}

Setiap hari selesai kegiatan kebersihan para siswa selalu tak lupa mengembalikan alat-alat kebersihan tersebut dengan semestinya dan rapi. Mereka juga menggunakan fasilitas sekolah dengan seperlunya, tidak berlebih-lebihan. Hal tersebut terlihat di beberapa ruangan tertentu yang ditempel oleh pihak sekolah maupun asrama yang bertuliskan peringatan untuk selalu menggunakan fasilitas dengan semestinya termasuk listrik dan air.

Sama halnya di sekolah, di asrama pun selesai kebersihan atau melaksanakan jadwal piket asrama, siswa selalu tak lupa mengembalikan alat-alat kebersihan pada tempatnya dengan tersusun rapi

Makanan yang tersedia di kantin sekolah SMA Negeri 4 Kabupaten Lahat dimasak sendiri dan kembali. Alat kebersihan pun dijaga dengan semestinya oleh para siswa dan siswi, yaitu menggunakan alat-alat tersebut sesuai kegunaannya seperti sapu lidi untuk membersihkan daun-daun di rumpu dan sebagainya.

Siswa yang tinggal di assrama, karena sudah terlatih untuk selalu bangun subuh dan terlatih mereka selalu menyelesaikan tugas di pagi hari sebelum kegiatan belajar-mengajar sekolah dimulai. Kegiatan siswa SMA Negeri 4 Kabupaten Lahat lebih banyak dihabiskan disekolah, dengan demikian setidaknya dapat menghemat penggunaan fasilitas di asrama.

Alat-alat kebersihan sekolah termasuk asrama di beli dari uang kas siswa dan siswi di SMA Negeri 4 Kabupaten Lahat tersebut. Sehingga mereka selalu menjaga alat-alat kebersihan tersebut agar tidak cepat rusak. Alat-alat kebersihan tersebut tetap dipakai selagi masih layak dipakai, hal tersebut selain ekonomis setidaknya mengurangi sampah yang seharusnya masih layak untuk digunakan.

SMA Negeri 4 Kabupaten Lahat juga menerapkan penghematan SDA seperti listrik, air dan alat tulis, hal itu terlihat dari adanya tulisan peringatan mengenai penggunaan air dan listrik untuk digunakan sebaik-baiknya sesuai dengan kebutuhan. Adanya peringatan tertulis seperti itu secara tidak langsung selalu mengingatkan siswa, sehingga secara tidak langsung menanamkan kesadaran dari dalam diri siswauntuk selalu melestarikan lingkungan guna mengurangi hawa panas di bumi atau pemanasan global.

\section{Peraturan yang Berlaku di Kantin}

Peningkatan kualitas makanan sehat di SMA Negeri 4 Kabupaten Lahat ini sudah cukup baik, peraturan yang telah dibuat oleh pihak sekolah dalam rangka menjadikan sekolah ramah lingkungan yaitu di kantin sekolah tidak menyediakan makanan yang berbentuk kemasan guna mengurangi sampah plastik yang dapat menyebabkan pemanasan global. Hal tersebut juga menjadikan makanan yang tersedia dikantin lebih sehat, karena makanan yang tersedia juga dimasak sendiri tanpa pengawet.

sudah passti tanpa pengawet, dan sudah pasti lebih sehat untuk dikonsumsi. Alat-alat yang digunakan 
pun lebih higenis dengan menggunakan mankok, piring, sendok dan cangkir. Setelah digunakan alatalat tersebut tak lupa dikembalikan lagi kekantin tempat memebeli makanan tersebut.

Makanan yang tersedia dan dijual di kantin sekolah SMA Negeri 4 Kabupaten Lahat juga selalu terjamin kebersihannya. Konsumen dari kantinsekolah tidak hanya siswa di sekolah tersebut tetapi guru-guru dan para staf juga membeli makanan di sana. Karena makanan yang tersedia di kantin sekolah sudah terpercaya kualitasnya, jadi siswa maupun guru tidak meragukan lagi untuk mengkonsumsi makanan tersebut.

\section{Bentuk Partisipasi Siswa dan Peralatan yang digunakan di Kantin Sekolah}

Siswa di SMA Negeri 4 kabupaten Lahat dengan kesadaran mereka masing-masing jika membawa makanan dari rumah menggunakan tempat atau wadah khusus untuk membawa makanan tersebut guna mengurangi sampah plastik. Jika mereka menggunakan atau makan di kantin sekolah, mereka tak lupa mengembalikan peralatan tersebut kepada pemiliknya.

Siswa SMA Negeri 4 Kabupaten Lahat tersebut bila selesai makan atau menggunakan alat-alat dari kantin, mereka menjaga dan tidak merusak alat-alat tersebut seperti mangkok, cangkir, piring dan sendok di kantin tersebut. Dengan demikian maka kantin di sekolah tertata dengan rapi dan bersih, serta alat-alat yang digunakan pun terjaga kebersihannya.

Siswa dengan kesadaran mereka masingmasing jarang sekali terlihat membawa atau membeli makanan dari luar yang berbentuk kemasan, selain mereka sadari bahwa kurang terjaga kesehatannya dan mengandung bahan pengawet, hal tersebut menyebabkan sampah. Apalagi mereka sangat menyadari bahwa sampah plastik sangat sulit untuk diuraikan.

\section{Pengelolaan Sampah}

Siswa di SMA Negeri 4 Kabupaten Lahat sangat inspiratif dan kreatif dalam mengelola barang bekas. Mereka dapat membuat segala sesuatu yang berguna, misalnya sampah seperti plastik ditergen, tempat air mineral yang berbentuk cup dapat mereka olah menjadi tas, tempat buah- buahan, sendal dan prakarya lainnya. Ekstrakurikuler yang ada di SMAN 2 Lahat juga sangat bervariatif dalam mengasah kreativitas dan bakat siswa-siswi. Hal ini di dukung dengan tenaga pendidik yang berkualitas.

Saat masuk kawasan SMA Negeri 4 kabupaten Lahat terlihat bahwa didepan meja tamu sesudah pos satpam berjejer contoh hasil karya-karya dari siswa-siswi SMA Negeri 4 Lahat tersebut di dalam sebuah lemari kaca dibariskan tersusun dan sejajar dengan piala-piala yang dipajang begitu banyaknya. Peneliti melihat kreatifitas siswa-siswi tersebut sangat kagum.

Kegiatan tersebut yaitu dengan membuat kreatifitas-kreatifitas dengan barang bekas seperti plastik selain mengurangi sampah dan pemanasan global, siswa dapat menjadikan barang bekas tersebut menjadi sesuatu yang bernilai jual. Dengan demikian siswa dapat juga menerapkan hal tersebut di lingkungan sekitar dan dimanapun mereka berada. Dari pengelolaan sampah oleh siswa yang kreatif tersebut kadang dapat menjadikan wirausaha untuk mereka sendiri.

\section{Hasil Observasi}

Berdasarkan hasil observasi yang diberikan secara langsung kepada siswa di SMA Negeri 4 Kabupaten Lahat, peneliti melihat setiap pagi kegiatan rutin siswa di SMA Negeri 4 Kabupaten Lahat setelah kegiatan imtaq yaitu bagi yang piket membersihkan ruang kelas dan ada juga yang gotong royong membersihkan lingkungan sekolah tanpa dikomando, setelah selesai melakukan kegiatan kebersihan sebelum memulai pelajaran siswa selalu mengembalikan alat-alat kebersihan ditempatnya semula dengan rapi kembali, misalnya sapu lidi dikembalikan lagi ketempat khusu sapu lidi.

Kawasan SMAN 4 Lahat juga sangat sejuk, hal ini karena sekeliling kawasan sekolah banyak terdapat taman-taman kecil dan pepohonan. Maret 2013 lalu Badan Lingkungan Hidup Kabupaten Lahat telah mengunjungi SMA Unggul Negeri 4 Lahat untuk mengadakan sosialisasi tentang biofori untuk memaksimalkan air yang meresap ke dalam tanah sehingga menambah air tanah, membuat kompos alami dari sampah organik daripada dibakar, mengurangi genangan air yang menimbulkan 
penyakit, mengurangi air hujan yang dibuang percuma, mengurangi resiko banjir di musim hujan, maksimalisasi peran flora dan fauna tanah, serta mencegah terjadinya erosi tanah dan bencana tanah longsor.

Peneliti juga melihat bahwa siswa di SMA Negeri 4 Kabupaten Lahat sudah menerapkan penggunaan, pengurangan dan pengelolaan atau daur ulang barang bekas menjadi sesuatu yang berguna, seperti yang terlihat di pajangan lemari yang khusus untuk kreasi-kreasi siswa. Hal itu menujukkan bahwa plastik bekas yang seharusnya menjadi sampah yang dapat menyebabkan hawa panas bumi, dengan kreativitas siswa tersebut maka mereka telah melakukan pelestarian lingkungan.

\section{Hasil wawancara}

Peneliti juga mewawancarai guru yang bersangkutan tentang adiwiyata tersebut, mereka menunjukkan bukti bahwa sekolah SMA Negeri 4 Kabupaten lahat benar-benar telah mendapatkan prestasi di bidang lingkungan hidup atau sekolah adiwiyata yaitu adanya piala yang terpajang di sekolah dan juga piagam adiwiyata serta lingkungan hidup yang ditempelkan di dinding ruang guru.

Kantin sekolah di SMA Negeri 4 Lahat sudah tidak lagi menyediakan makanan yang berbentuk kemasan seperti plastik untuk menhindari sampah, jadi alat-alat yang digunakan dikantin sekolah yaitu seperti cangkir, piring dan mangkok, jadi jika sudah dipakai maka harus dikembalikan lagi ke kantin. Sebagian siswa yang membawa makanan dari rumah, mereka menggunakan wadah khusus. Siswa disini juga tidak membawa makanan dari luar yang bentuk kemasan plastik.

SMA Negeri 4 Kabupaten Lahat ini sudah menerapkan 3R (reduce, reuce,recycle) yaitu mengurangi pemakaian, memakai kembali dan daur ulang, hal ini terlihat bahwa SMAN 4 Lahat sudah menerapkan penghematan listrik dengan membatasi pemakaian atau digunakan seperlunya saja, barang atau alat-alat yang tersedia di sekolah harus

Hal itu berkaitan dengan penelitian terdahulu oleh Srikandi Ningsih (2014) mengenai pengelolaan lingkungan hidup dalam program adiwiyata, ia mengatakan bahwa kegiatan dalam program adiwiyata yang bertujuan menjaga dan melestarikan digunakan sebaik-baiknya misalnya barang yang masih layak dipakai atau masih dapat diperbaiki maka masih dapat digunakan kembali.

Selain mengurangi penggunaan plastik di sekolah, siswa disini juga diasah kreativitasnya untuk membuat prakarya dari barang-barang bekas atau plastik menjadi sesuatu yang berguna dalam upaya mengurangi sampah plastik yang dapat berdampak pemanasan global. Tidak hanya plastik, sisa kertas dan daun pun dapat dijadikan siswa SMAN 4 Lahat ini pajangan atau hiasan yang indah, hal ini dapat dilihat saat kita memasuki kawasan SMAN 4 Lahat, disana terlihat sederetan karyakarya siswa-siswi di SMAN 4 Lahat yang sengaja disusun dalam lemari kaca sedemikian rupa. Selain itu program adiwiyata SMAN 4 Lahat dilihat dari pengembangan kebijakan sekolah peduli dan berbudaya lingkungan, pengembangan kurikulum berbasis lingkungan, pengembangan dan pengelolaan sarana pendukung sekolah secara umum sudah berjalan dengan baik.

Siswa SMAN 4 Lahat telah mempraktikkan atau menerapkan langsung cara pembuatan biofori di halaman sekolah. Kegiatan ini mencerminkan SMA Unggul Negeri 4 Lahat ikut serta dalam melestarikan kondisi alam sekitar, sehingga hal tersebut dapat mengurangi pemansan global di sekolah maupun di masyarakat.

Setelah dilakukan penelitian pada tanggal 2630 Juli hasil yang diperoleh dari wawancara secara langsung kepada siswa dan guru sebagai informan yang terdiri dari 5 pertanyaan dari tiga indikator yaitu indikator yang pertama mengenai keikutsertaan siswa dalam pengelolaan lingkungan hidup di sekolah, mencegah terjadinya pencemaran dan kerusakan lingkungan hidup yang termasuk dalam program adiwiyata. Siswa berperan aktif dalam kegiatan melestarikan lingkungan sekolah dengan melakukan kegiatan piket setiap hari, serta bersama-sama membersihkan lingkungan sekitar sekolah.

lingkungan hidup secara baik juga bertujuan untuk mendidik siswa dalam mengelola lingkungan hidup secara baik dan benar.

Indikator yang kedua yaitu, peningkatan kualitas pelayanan makanan sehat. Program 
adiwiyata ini sangat mendukung terjadinya lingkungan yang bersih, karena dengan adanya program adiwiyata maka disekolah akan mengurangi penggunaan makanan berbentuk kemasan (plastik) di kantin sekolah yang dapat menyebabkan pencemaran lingkungan.

Kaitannya dengan pemanasan global bahwa sampah plastik sangat sulit untuk diuraikan, butuh waktu ratusan bahkan jutaan tahun untuk penguraiannya, sedangkan sampah plastik saat ini masih menjadi masalah terbesar di bumi. Masih banyaknya penggunaan sampah plastik dan kaleng inilah yang menyebabkan bumi semakin panas.

Selanjutnya, indikator yang ketiga yaitu mengenai pengembangan sistem pengelolaan sampah. Adanya program adiwiyata ini sangat baik untuk pendidikan lingkungan hidup di sekolah. Upaya yang telah dilakukan siswa di SMA Negeri 4 Kabupaten Lahat dalam mengurangi pemanasan global yaitu tidak hanya membuang sampah pada tempatnya, tetapi siswa dapat membuat terobosan atau inovasi-inovasi baru yang membangun sehingga membuat barang bekas seperti plastik bekas air mineral dan plastik-plastik lainnya menjadi sesuatu barang yang berguna dan dapat dipakai dalam kehidupan sehari-hari.

Program Adiwiyata ini sangat memberikan dampak yang sangai baik jika berjalan dengan baik, dan yang tak kalah pentingnya partisipasi siswa dan guru dalam mengolah lingkungan sekolah tersebut. Hal inilah yang terjadi di SMA Negeri 4 Kabupaten Lahat, sebagai generasi muda siswa SMA Negeri 4 Kabupaten Lahat ini sudah sangat bagus dalam mengolah lingkungan sekolahnya, kesadaran akan kebersihan lingkungan juga sudah tertanam dalam diri mereka sehingga mereka merasa memiliki tanggung jawab akan kebersihan lingkungan. Otomatis hal tersebut akan memberikan dampak positif dimanapun siswa tersebut berada, termasuk ketika berada dilingkungan luar sekolah.

Kegiatan atau partisipasi siswa dalam menjaga lingkungan hidup dengan melestarikan tanaman juga pepohonan di sekolah, seperti yang terlihat di sekeliling lingkungan sekolah SMA Negeri 4 Kabupaten Lahat banyak sekali tanaman dan rerumputan, hal itu dapat mengurangi hawa panas sehingga akan mengurangi pemanasan global.
Selain itu guna mengurangi pemanasan global atau hawa panas di sekolah, pihak sekolah dan didukung dengan peran siswa di SMA Negeri 4 Lahat juga menerapkan penghematan sumber daya alam seperti listrik dan air di asrama maupun di sekolah. Dengan demikian program adiwiyata dalam mengurangi pemanasan globaldi SMA Negeri 4 Lahat sudah dilaksanakan dengan baik, sehingga lingkungan sekitar sekolah terasa sejuk.

\section{SIMPULAN}

Berdasarkan hasil penelitian yang telah dilakukan di SMA Negeri 4 Lahat dapat disimpulkan bahwa:

1) Peran siswa di SMA Negeri 4 Lahat pada program adiwiyata guna mengurangi pemanasan global di sekolah sudah berjalan dengan baik, didukung dengan sudah diterapkannya penghematan sumber daya alam seperti listrik dan air di asrama maupun di sekolah, sehingga lingkungan sekitar sekolah terasa sejuk.

2) Kualitas pelayanan makanan sehat, SMA Negeri 4 Kabupaten Lahat sudah tidak menyediakan makanan dalam bentuk kemasan di kantin sekolah. Selain itu SMA Negeri 4 Lahat juga menyediakan asrama bagi siswa, dengan adanya asrama juga sedikit membantu dalam mengurangi polusi udara dari kendaraan bermotor, serta pengelolaan sampah menjadi sesuatu yang berguna atau dimanfaatkan kembali serta dapat dimanfaatkan sebagai pupuk.

\section{DAFTAR PUSTAKA}

Alikodra, Hadi. (2008). Global Warming (Banjir dan Tragedi Pembalakan Hutan). Bandung: Nuansa.

Arikunto, Suharsimi. (2010). Prosedur Penelitian Suatu Pendekatan Praktik. Jakarta: Rineka Cipta.

Kerjasama Kementrian Lingkungan Hidup dengan Kementrian Pendidikan dan Kebudayaan. (2012). (diakses Rabu, 26 Oktober 2016. Pukul 06.03).

Mahmud.. (2011). Metode Penelitian Pendidikan. Bandung: Pustaka Setia. 
Ningsih, Srikandi. (2014). "Persepsi Siswa pada Program Adiwiyata dalam Pengelolaan Lingkungan Hidup di SMP Negeri 55 Palembang”.Skripsi S1 (belum diterbitkan). Palembang: FKIP Universitas PGRI Palembang.
Sugiyono. (2009). Metode Penelitian Kuantitatif Kualitatif dan $R \& D$. Bandung: Alfabeta.

Sugiyono. (2014). Metode Penelitian Pendidikan (Pendekatan Kuantitatif, Kualitatif, dan R\&D). Bandung: Alfabeta.

Panduan Adiwiyata Sekolah Peduli dan Berbudaya Lingkungan. (2011). Panduan Adiwiyata 